\title{
Effects of remifentanil on cognitive and psychomotor functioning and mood
}

Citation for published version (APA):

Münte, S., Quaedflieg, C. W. E. M., Sambeth, A., Wang, M., \& Kalso, E. (2013). Effects of remifentanil on cognitive and psychomotor functioning and mood. British Journal of Anaesthesia, 111(3), 517-518. https://doi.org/10.1093/bja/aet277

Document status and date:

Published: 01/09/2013

DOI:

10.1093/bja/aet277

Document Version:

Publisher's PDF, also known as Version of record

Document license:

Taverne

Please check the document version of this publication:

- A submitted manuscript is the version of the article upon submission and before peer-review. There can be important differences between the submitted version and the official published version of record.

People interested in the research are advised to contact the author for the final version of the publication, or visit the DOI to the publisher's website.

- The final author version and the galley proof are versions of the publication after peer review.

- The final published version features the final layout of the paper including the volume, issue and page numbers.

Link to publication

\footnotetext{
General rights rights.

- You may freely distribute the URL identifying the publication in the public portal. please follow below link for the End User Agreement:

www.umlib.nl/taverne-license

Take down policy

If you believe that this document breaches copyright please contact us at:

repository@maastrichtuniversity.nl

providing details and we will investigate your claim.
}

Copyright and moral rights for the publications made accessible in the public portal are retained by the authors and/or other copyright owners and it is a condition of accessing publications that users recognise and abide by the legal requirements associated with these

- Users may download and print one copy of any publication from the public portal for the purpose of private study or research.

- You may not further distribute the material or use it for any profit-making activity or commercial gain

If the publication is distributed under the terms of Article $25 \mathrm{fa}$ of the Dutch Copyright Act, indicated by the "Taverne" license above, 


\section{Consent in Jehovah's Witnesses}

Editor-Sydor and colleagues ${ }^{1}$ studied trainee behaviour in a crisis situation, and trainee ability to challenge a decision by a consultant anaesthetist to administer blood to a patient who is a Jehovah's Witness. This was described as unethical, although perhaps a better term would be 'in breach of the law'.

I would like to put it to the authors that unless the notes were shown to contain the proper Advance Decision, the consultant anaesthetist's decision could have been ethical and legal. In the UK, the legal position is that in the case of lifesustaining treatment, the advance decision must be made by an adult who has capacity, needs to be in writing, signed in the presence of a witness, and it must include a clear statement that the advance decision is to apply to the specific treatment even if the decision maker's life is at risk. If any of the above conditions are not fulfilled, the doctor then must act in the patient's best interests. It is not clear from the scenario whether such a form was included in the notes. 'Consult' done by a trainee on call overnight was fairly brief, with no mention of Advance Decision.

While it is important to respect the wishes of a Jehovah's Witness, it is also important to establish exactly what those wishes are and whether they have a legal standing. The ethical standpoint of the doctor is thus also respected, and any future legal challenge prevented.

\section{Declaration of interest}

None declared.

S. Dolenska

Kent, UK

E-mail: sylva.dolenska@nhs.net

1 Sydor DT, Bould MD, Naik VN, et al. Challenging authority during a life-threatening crisis: the effect of operating theatre hierarchy. Br J Anaesth 2013; 110: 463-71

doi:10.1093/bja/aet279

\section{Potential confounder in the ethical dilemma of challenging authority}

Editor-I read with interest the study by Sydor and colleagues ${ }^{1}$ examining the responses of trainee anaesthetists when faced with the 'unethical' actions of a senior colleague in a simulated clinical crisis. Being able to challenge colleagues when motivated by the need to avert an adverse event is an important non-technical skill, and study of the factors that influence this ability is interesting and worthwhile. However, I note that the unethical action the authors created at the centre of the simulation was that of giving a blood transfusion to an anaesthetized Jehovah's Witness suffering a severe intraoperative haemorrhage with life-threatening features of cardiac ischaemia. I wonder whether this represents a confounding factor in their study. Although the authors cite legal precedent regarding blood transfusion of a Jehovah's Witness patient against their express wishes, I would not agree that such an act is unambiguously and consistently unethical. The bioethics concerning the dominance of the principle of autonomy in refusal of blood transfusion regardless of severe harm or death are not particularly straightforward. ${ }^{2}$ Having professional experience of an intraoperative death due to post-partum haemorrhage in a Jehovah's Witness who refused blood and whose pre-existing wishes were honoured, I can vouch that the option to give blood products in an attempt to preserve life was hotly debated during the events and for some time afterwards. The authors describe this as 'a clearly unethical decision', which is at best overstated. The authors express surprise at the omission and commission of their subjects. However, the fact that many people will fail to challenge and even actively participate in a definitely unethical act under the influence of authority is well accepted ${ }^{3}$ and is probably a part of normal human psychology. I suggest that the study by Sydor and colleagues would have been stronger if the 'unethical' proposition the participants were faced with was unequivocally unethical.

\section{Declaration of interest}

None declared.

D. Nethercott

Bolton, UK

E-mail:daniel.nethercott@boltonft.nhs.uk

1 Sydor DT, Bould MD, Naik VN, et al. Challenging authority during a lifethreatening crisis: the effect of operating theatre hierarchy. $\mathrm{Br} J$ Anaesth 2013; 110: 463-71

2 Muramoto 0 . Bioethics of the refusal of blood by Jehovah's Witnesses: Part 3. A proposal for a don't-ask-don't-tell policy. J Med Ethics 1999; 25: 463-8

3 Milgram S. Behavioural study of obedience. J Abnormal Soc Psychol 1963; 67: 371-8

doi:10.1093/bja/aet276

\section{Effects of remifentanil on cognitive and psychomotor functioning and mood}

Editor-In this double-blind, placebo-controlled, cross-over study, we examined the effects of remifentanil on cognitive and psychomotor function, mood, and subjective feelings, including the exploration of gender differences during a steadystate target-controlled infusion (TCI) of low-dose remifentanil, which has not been reported before. As a potent, ultra-shortacting $\mu$-opioid receptor agonist remifentanil has a unique pharmacokinetic profile which makes it an attractive drug for the study of opioid effects. Our hypothesis was that remifentanil impairs cognitive and psychomotor function and affects subjective feelings and that there might be gender differences in these effects. 


\section{Overview Testday}

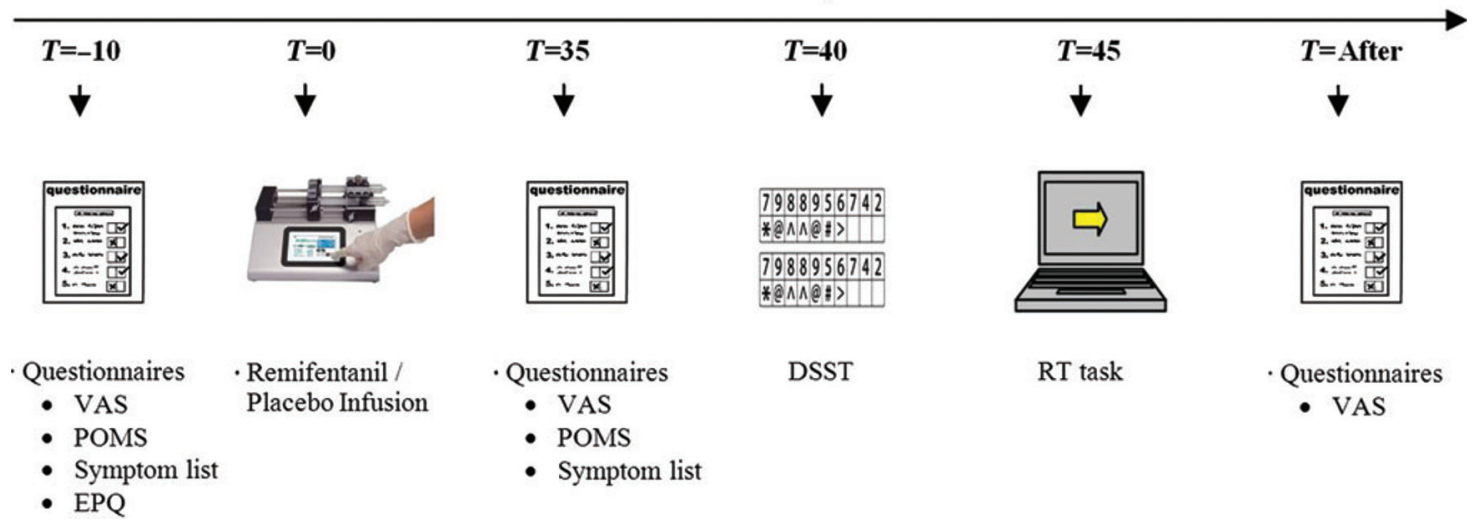

Fig 1 Overview of test day: 2 test days with placebo or remifentanil infusions, at least 3 days apart, each $3 \mathrm{~h}$ in duration. T, time; VAS, visual analogue scale, we used 12 consisting of items related to subjective feelings and adverse effects of the drug; POMS, profile of mood states. The POMS is a 65 -item, adjective rating scale designed to measure multiple dimensions of effect. Symptom list consisting of 28 items on a scale of 1 'Not at all' to 5 'Extremely'. DSST, Digit Symbol Substitution Test, is a subscale of the Wechsler Adult Intelligence Scale and has been used to assess information processing (attention, working memory, perceptual speed, motor speed, and visuo-motor coordination). RT, the visual choice Reaction Time test ${ }^{10}$ measures, apart from simple motor performance and speed, eye-hand coordination, attention, and decision-making.

Twenty healthy volunteers ( 10 men and 10 women) aged 18-40yr were included. On two test days, participants received remifentanil or placebo (saline) in a randomized cross-over design. Remifentanil was administered at an effect-site concentration of $1 \mathrm{ng} \mathrm{ml}^{-1}$ using a TCI pump. The dose was chosen from previous fMRI studies which showed an analgesic effect of this dose without excessive sedation or blood oxygen desaturation. ${ }^{1}$ Drug effects were measured using a Digit Symbol Substitution Task (DSST), choice reaction time (RT), visual analogue scales (VAS), a Symptom List, and the Profile of Mood States (POMS) questionnaire (Fig. 1). Data were analysed using repeated-measures analysis of variance. Differences with $P<0.05$ were considered as statistically significant.

Remifentanil slowed down psychomotor function as seen in a significantly increased RT (401 vs 373 ms), but did not affect cognitive performance on the DSST. During remifentanil infusion, participants felt more sleepy, confused, dizzy, and had more itchy skin. Women felt sleepier and tended to feel more sad and nauseous than men. On the POMS questionnaire, remifentanil increased vigour, fatigue, and feeling confused in both genders, but had no dysphoric effects on participants.

Since cognitive and psychomotor functioning (e.g. memory, attention, visuo-motor coordination) are essential during recovery from sedation and anaesthesia, knowledge of these effects for individual drugs is useful for a clinician, for example, to evaluate the home-readiness of patients. In addition, remifentanil caused sedation, fatigue, and confusion in participants, but at the same time, they felt more vigour. Women felt stronger sedated and had more side-effects than men. Approximately $30 \mathrm{~min}$ after remifentanil infusion as the TCI reached an effect-site concentration of $0.0 \mathrm{ng} \mathrm{ml}^{-1}$, participants still felt dizzy [VAS score 2.95 (1.0) $\mathrm{mm}, P=0.007$ ], but all other subjective feelings had returned to baseline.

\section{Declaration of interest}

None declared.

S. Münte ${ }^{1 *}$

C. W. E. M. Quaedflieg ${ }^{2}$

A. Sambeth ${ }^{2}$

M. Wang ${ }^{3}$

E. Kalso ${ }^{1}$

${ }^{1}$ Helsinki, Finland

${ }^{2}$ Maastricht, The Netherlands

${ }^{3}$ Leicester, UK

*E-mail: sinikka.munte@hus.fi

1 Wise RG, Williams P, Tracey I. Using fMRI to quantify the time dependence of remifentanil analgesia in the human brain. Neuropsychopharmacology 2004; 29: 626-35 